\title{
Investigation of Drug Dose Calculation Skills and Self-Ratings Among Nursing Students
}

\author{
Ilaç Doz Hesaplama Becerilerinin ve Öz Değerlendirmelerinin Hemşire \\ Grubunda Araştırılması
}

\author{
Zeynep Güneş Özünalథ, Tuğçe Boran $\oplus$, Esra Sağlam® \\ Maltepe University Medical Faculty Medical Pharmacology Department, istanbul, Turkey
}

Received: 06 February 2020 / Accepted: 03 March 2020 / Publication date: 26 March 2020

Cite as: Özünal ZG, Boran T, Sağlam E. Investigation of drug dose calculation skills and self-ratings among nursing students. Med J Bakirkoy 2020;16(1):71-5.

\section{ABSTRACT}

Objective: Medication errors are important concerns in terms of patient safety. Dose calculation skills contribute to medication errors. The aim of this study is to evaluate the calculation skills and self-ratings of nursing students.

Method: Four multiple-choice questions with five alternative responses were asked and an electronic questionnaire form was used for the assessment of their perceptions of their self-competencies.

Results: The rates of correct answers to the questions varied between $20 \%$ and $63 \%$. In their self-assessments, $26.4 \%$ of them stated that they had sufficient dose calculation skills.

Conclusion: The results of the study showed that skills should be improved. Drug dose calculation skills should be improved, and further education should be provided on this issue.

Keywords: pharmacology, education, medication errors

Öz

Amaç: Ilaç hataları, hasta güvenliliği için önemlidir. Doz hesaplama becerileri ilaç hatalarına neden olabilir. Bu çalışma hemşirelik öğrencilerinin ilaç doz hesaplama becerilerini değerlendirmeyi ve yeterliliklerinin öz değerlendirmelerinin araştırılmasını amaçlamaktadır.

Yöntem: Dört adet beş seçenekli çoktan seçmeli soru soruldu ve kendi yeterliliklerini algılamalarını değerlendirmek için elektronik form kullanıldı.

Bulgular: Doz hesaplama sorulara doğru cevap \% 20 ile\% 63 arasında değişmekteydi. Öz değerlendirmelerinde, \% 26.4 'ü doz hesaplama becerileri için yeterli olduğunu belirtti.

Sonuç: Çalışmanın sonuçları becerilerin geliştirilmesi gerektiğini göstermiştir. ilaç dozu hesaplama becerilerinin arttırılması ve daha fazla eğitime ihtiyaç vardır.

Anahtar kelimeler: farmakoloji, eğitim, ilaç hatası 


\section{INTRODUCTION}

Patient safety is an important concern that dates back to the first declaration of "primum non nocere". Medication errors are reported to cause more deaths from motor vehicle accidents, breast cancer, or workplace injuries ${ }^{(1)}$. To increase patient safety and decrease medication errors; all integrated medication delivery process from prescribing, transcribing, dispensing to administering medications is under the microscope ${ }^{(2)}$. There are many factors that may lead to medication errors. Lack of knowledge of prescribing skills, lack of pharmacological knowledge of physicians and nurses, poor compliance with drug prescribing and administration guidelines, lack of reporting of medication errors, heavy workload and being new staff, factors related to communication between health care professionals can result in a medication error ${ }^{(3)}$. In England and Wales, medication incident reports represented $9.68 \%$ of all patient safety incidents and $15 \%$ of medication incidents were about the incorrect dosages ${ }^{(4)}$. In Middle East countries incorrect dosage is also found to be within the most common types of errors ${ }^{(3)}$. Medication errors may stem from primarily physicians and nurses. Wrong dosages are reported to be in the context of nurse- related medication errors.

In Maltepe University School of Nursing curriculum, nursing-specific pharmacology lectures take two hours a week as a one-semester course in the second year, totaling 28 hours. Students have the opportunity to take this course in different years. The content of drug dose calculation is included in the pregraduate pharmacology course.

In this study, it was aimed to evaluate the dose calculation of the nursing students and also to investigate their self-ratings of their competence.

\section{MATERIALS and METHODS}

The was a retrospective descriptive study in Nursing Pharmacology Course in Maltepe University. To determine the dose calculation skills, students in the first, second and fourth-years at the School of Nursing who took the Nursing Pharmacology Course were evaluated.
Nursing students were asked four multiple choice questions with five alternative responses about evaluating their dose calculation skills in their final exam. The questions were prepared in accordance with a previous study in this field ${ }^{(5)}$. The answers were provided with optical forms. Marking the right choice among the five-choices was considered as "correct", marking other than the correct choice as "incorrect". Questions left blank were considered unanswered. Correct response rates were calculated, and results were evaluated retrospectively. Students' answers to multiple-choice questions were evaluated anonymously. The correct and incorrect answers of the students were calculated by using descriptive statistical methods and their frequencies were calculated using SPSS 25 . The participation rate was calculated by dividing the number of surveys by the total number of students.

An electronic questionnaire form consisting of eighteen questions was constructed to maintain the feedback about the course. The self-rating of competence in dose calculation was included in the questionnaire. A Likert scale was used to rate responses obtained. The link of the electronic questionnaire was announced to the class by the student representative. In the self-assessment of their competence, no information was received about the respondent. Participation in the electronic questionnaire was based on volunteriness. The study was performed in compliance with the guidelines of the Helsinki Declaration.

\section{RESULTS}

A total of 120 nursing students attended the final examination. The examination consisted of forty questions. Four multiple-choice questions on dose calculation skills were responded correctly by $60 \%$, $20 \%, 59 \%$, and $63 \%$ of the respondents according to the question order. The highest accuracy rate was related to the calculation of the dose of oral antibiotics used in childhood. Total dose of insulin dose was correctly indicated in $\% 60$ of the responses. Morphine related question was responded incorrectly at a rate of $\% 80$ and 9 students even did not answer this question.

Self-rating of electronic questionnaire response rate 
Table 1. Rates of correct, and incorrect answers to four questions about calculation of drug doses.

\begin{tabular}{|c|c|c|}
\hline Questions & True n (\%) & False $\mathrm{n}(\%)$ \\
\hline 1. In stock, you have insulin $100 \mathrm{U} / \mathrm{ml}$. You need to inject $28 \mathrm{U}$. How many $\mathrm{ml}$ do you have to inject? & 72 (60\%) & $47(39.17 \%)$ \\
\hline $\begin{array}{l}\text { 2. In stock, you have morphine } 3 \%(1 \%=1 \mathrm{~g} / 100 \mathrm{ml}) \text {. How many } \mathrm{mg} \text { morphine does one ampoule of } \\
2 \mathrm{ml} \text { contain? }\end{array}$ & $24(20 \%)$ & $96(80 \%)$ \\
\hline $\begin{array}{l}\text { 3. You need to administer } 25 \mathrm{mg} \text { furosemide per hour via an infusion pump. One } 10 \mathrm{ml} \text { ampoule con- } \\
\text { tains } 100 \mathrm{mg} \text { of furosemide. When you have to set up the infusion pump, how many ml/hour do you } \\
\text { program? }\end{array}$ & $71(59.16 \%)$ & $28(23.33 \%)$ \\
\hline $\begin{array}{l}\text { 4. A child of } 30 \mathrm{~kg} \text { needs antibiotics at a dosage of } 4 \mathrm{mg} / \mathrm{kg} / \text { day. In stock, you can find ampoules of } 100 \\
\mathrm{mg} / 5 \mathrm{ml} \text {. How many } \mathrm{ml} \text { do you administer per day? }\end{array}$ & $76(63.33 \%)$ & $44(36.67 \%)$ \\
\hline
\end{tabular}

TBSA: Total body surface area, ${ }^{*} p<0.05$ was considered as statistically significant

was $65 \%(n=74)$. Self-rated competency in dose calculation skills was $31.9 \%(n=23)$ Eighteen $(25 \%)$ participants indicated that they felt themselves completely incompetent. While $12(9.7 \%)$ respondents had no idea about the subject ("undecided group"), and 12 participants indicated that they felt themselves completely competent

\section{DISCUSSION}

Nursing education at a university level has been started in 1955 in Turkey ${ }^{(6)}$. Turkey was reported to be one of only five European countries providing a basic university-level nursing education with Belgium, England, Greece, and Iceland (7). In Turkey nursing education is regulated with national and international guiding principles; and curriculum of nursing education involves 4,600 hours of theoretical and practical training ${ }^{(6,8)}$. A total of 26 hours in pharmacology courses may not be sufficient to teach adequately all aspects of the medications. Since it is very important for nursing practice, it is suitable to be included not only in pharmacology course content but also in other courses. Drug dose calculation should be included in different course titles. There should be a better correlation between nursing education outputs and needs in nursing practices.

The rates of correct answers to the second question asked in the exam were at the lowest level with $20 \%$, and to the fourth question were at the highest level with $63.33 \%$. Although rates of correct answers vary according to the question, question related to dose calculation was responded by higher number of par- ticipants when compared with those concerning selfperceived competencies The students also stated that they had difficulty in calculating oral doses.

The questions about drug dose calculations are prepared in reference to the study by Dills et al. ${ }^{(5)}$ Although these doses and drugs may not represent the medications in our country, the participants were asked to evaluate their calculation skills so as to be able to compare the correct response rates.

In our study, correct answers were obtained at a rate of $60 \%$ for the question about insulin dose calculation (question 1, Table 1), while the relevant rate in the reference study was $61.8 \%$ for the same question in the other sample group. The correct dose of high-risk drugs such as insulin is important. Indeed, inappropriate doses, can lead to life-threatening clinical conditions such as hypoglycemia and hyperglycemia. Knowledge of high-risk drugs by nurses and proper labeling of high-risk drugs by the pharmacy can contribute to increased awareness of nurses. Insulins also differ according to their duration of action. It is important to plan nurses' postadministration follow-up according to the duration of insulin administered.

Second question was correctly answered by $20 \%$ of the participants, whereas accuracy rate for this question was $28.9 \%$ in Belgium ${ }^{(5)}$. For the safety of controlled and high-risk drugs, such as morphine, it is particularly important to calculate the dose ccrrectly. In our study, the last question was answered correctly by $59.16 \%$ of the participants while this rate 
was $67.5 \%$ in the reference study ${ }^{(5)}$. Dose calculation is important for drugs; given in perfusion solutions. These drugs may represent separate challenges for nurses due to the choice of appropriate device, changing models, and the need for automatic dose calculation to be controlled by nurses. In terms of electrolyte and fluid imbalance, the dose and duration of administration of furosemide and similar drugs are important. Fluid monitoring and nursing followup are vital.

The fourth question was about antibiotic dose in the pediatric age group. The rate of correct answers was $63.33 \%$ in our study and $65.6 \%$ in the study in Belgium. Lack of mathematical knowledge on the calculations skills in other studies performed at two different nursing schools in Turkey negatively effected the rates of correct answers, and, students in these studies reported that they had poor mathematical skills ${ }^{(9)}$. In our study students' mathematical skills have not been evaluated. Therefore, it is not known whether the incorrect answers given to the dose calculation questions stem from the students' inability to perform mathematical operations. Mathematical skill is reported as it is not the factor for insufficiency in dose calculating ${ }^{(10)}$.

In a study conducted in the UK, it was concluded that students' drug dose calculation skills were not very different from working nurses ${ }^{(11)}$. In another study conducted in Finland, it was shown that nurses working in the study area had better mathematical skills than nursing students ${ }^{(12)}$. In-service training or experience may serve to improve the capacity.

There is a perception of insufficiency in their own dose calculation skills in nursing students. It may point out a need for further education in undergraduate education and/or in-service training courses. Physicians should be aware of the weakness and strengths of the health care team they work with. Medication errors also may be due to prescription errors by physicians. Further studies are needed to evaluate the dose calculation skills of medical students.

One of the limitations of the study was evaluation of only one nursing school. In addition, students' response rates to the electronic questionnaire form was at a low level. Therefore, it should be taken into consideration that the answers do not reflect the opinions of the whole class and the interest and success of the course may affect the response rates. The assessment method, namely the multiple-choice question format was different from the reference study. The data were collected retrospectively, which may be an advantage when compared with a prospectively designed study. If the assessment of dose calculation skills was made in a prospectively designed study there might be a bias of participation of the students who felt more competent.

\section{CONCLUSION}

Correct response rates of nursing students to the questions about dose calculation ranged from $20 \%$ to $63.3 \%$. Increasing the accuracy of dose calculation is important to avoid medication errors. There is a need to improve training outcomes to increase rates of accuracy.

Ethics Committee Approval: Approval was obtained from Maltepe University Ethics Committee (20.01.2020, decision no. 2020 / 01-27 /).

Conflict of Interest: The authors declare that there is no conflict of interest regarding the publication of this article.

Funding: The authors received no financial support for the research.

Informed Consent: Informed consent is not required to the retrospective studies.

\section{REFERENCES}

1. Medicine Io. In: Kohn LT, Corrigan JM, Donaldson MS, editors. To Err is Human: Building a Safer Health System. Washington (DC): National Academies Press (US); 2000.

2. Benjamin DM. Reducing medication errors and increasing patient safety: Case studies in clinical pharmacology. J Clin Pharmacol. 2003;43(7):768-83. https://doi.org/10.1177/0091270003254794

3. Alsulami Z, Conroy S, Choonara I. Medication errors in the Middle East countries: A systematic review of the literature. Eur J Clin Pharmacol. 2013;69(4):995-1008. https://doi.org/10.1007/s00228-012-1435-y

4. Cousins DH, Gerrett D, Warner B. A review of medication incidents reported to the National Reporting and Learning System in England and Wales over 6 years (2005-2010). Br J Clin Pharmacol. 2012;74(4):597-604. https://doi.org/10.1111/j.1365-2125.2011.04166.x

5. Dilles T, Vander Stichele RR, Van Bortel L, Elseviers MM. Nursing students' pharmacological knowledge and calculation skills: ready for practice? Nurse Educ Today. 2011;31(5):499505. 
https://doi.org/10.1016/j.nedt.2010.08.009

6. Ergol S. Nursing education in higher education in Turkey. Journal of Higher Education and Science. 2011;1(3):152. https://doi.org/10.5961/jhes.2011.022

7. Thobaben $M$, Roberts DA, Badir A, Wang $H$, Murayama $H$, Murashima $S$, et al. Exploring nursing education in the People's Republic of China, Japan and Turkey. Contemp Nurse. 2005;19(1-2):5-16.

https://doi.org/10.5172/conu.19.1-2.5

8. Pektekin Ç. Türkiye'de hemşirelik/ebelik eğitiminin konumu, ulusal sağlık eğitimi politikasi ve öneriler. F N Hem Derg. 1991;5(19):93-9.

9. Guneş UY, Baran L, Kara Yilmaz D. Mathematical and Drug Calculation Skills of Nursing Students in Turkey. International
Journal of Caring Sciences. 2016;9(1):220-7.

10. Wright K. Student nurses need more than maths to improve their drug calculating skills. Nurse Educ Today. 2007;27(4):27885. https://doi.org/10.1016/j.nedt.2006.05.007

11. McMullan M, Jones R, Lea S. Patient safety: Numerical skills and drug calculation abilities of nursing students and registered nurses. J Adv Nurs. 2010;66(4):891-9. https://doi.org/10.1111/j.1365-2648.2010.05258.x

12. Grandell-Niemi H, Hupli M, Leino-Kilpi H, Puukka P. Finnish nurses' and nursing students' pharmacological skills. J Clin Nurs. 2005 Jul;14(6):685-94

https://doi.org/10.1111/j.1365-2702.2005.01131.x 